\title{
The Effect of Hibiscus Flower Extract (Hibiscus rosa-sinensis L.) On the Growth of Streptococcus sanguinis Bacteria
}

\author{
Ranty Dwi Farasayu ${ }^{1}$, Mayu Winnie Rachmawati ${ }^{1}$, Ika Dewi Ana ${ }^{1}$, Ahmad Syaify $^{2}$, and Dyah Listyarifah ${ }^{1,3}{ }^{*}$ \\ ${ }^{1}$ Department of Dental Biomedical Sciences, Faculty Dentistry, Gadjah Mada University, 55281 Yogyakarta, Indonesia \\ ${ }^{2}$ Department of Periodontology, Faculty Dentistry, Gadjah Mada University, 55281 Yogyakarta, Indonesia \\ ${ }^{3}$ Integrated Research Laboratory, Faculty of Dentistry, Universitas Gadjah Mada, Yogyakarta, Indonesia
}

\begin{abstract}
According to the data of Global Burden Disease in 2016, periodontal disease is the $11^{\text {th }}$ disease suffered by 750,487 people worldwide. Gingivitis occurs due to dental plaque formation. A half of bacterial plaque populations are Streptococcus sp. Streptococcus sanguinis is a predominant bacterial that initiates plaque formation. The adherence of this bacteria is mediated by fimbriae, pilus protein, lipoprotein, and glucosyltransferase enzymes. Hibiscus flower has a potential as an antimicrobial agent that may inhibit plaque formation due its active component i.e. flavonoid, tannins, and saponin. This study aimed to investigate the effect of Hibiscus rosa-sinensis L. flower extract concentration on the growth of Streptococcus sanguinis. Wells diffusion method was used in this study, using $100 \mu 1$ bacterial suspension of $1,5 \times 10^{8} \mathrm{CFU} / \mathrm{ml}$ of bacteria. Hibiscus flower extract $(2 \%, 4 \%, 6 \%)$, chlorhexidine $0,12 \%$ as a positive control, and distilled water as a negative control were added in the agar wells. The results showed that all concentrations $(2 \%, 4 \%, 6 \%)$ of Hibiscus flower extract higher significantly compared to negative control. The concentration of $4 \%$ and $6 \%$ are higher ;significantly compared to positive control. The largest inhibitory zone was at a concentration of $6 \%(6,35 \pm 0,09 \mathrm{~mm})$ and the smallest inhibitory zone was at a concentration of $2 \%(2,51 \pm 0,12 \mathrm{~mm})$. The conclusion is that the concentration of Hibiscus rosa-sinensis L. flower extract affects the growth of Streptococcus sanguinis.
\end{abstract}

Key words: Kembang Sepatu Flower (Hibiscus rosa-sinensis L.), Hibiscus flower extract, Streptococcus sanguinis, zone of hibition, antibacterial.

\section{Introduction}

Based on the results of the 2016 Global Burden of Disease study, periodontal disease is the 11 th disease that affects 750,487 people worldwide [1]. Periodontal diseases such as gingivitis are induced by the accumulation of dental biofilm plaques. The accumulation of dental biofilm plaques will disrupt the balance of oral microbiome, known as dysbiosis, which further stimulates the host inflammatory response called plaque-induced gingivitis. The left untreated gingivitis will lead to periodontitis, a severe form of periodontal inflammation involving soft and hard tissue destruction. [2]. Gingivitis is usually painless and occasionally leads to spontaneous bleeding [3].

Streptococcus sp. covers $50 \%$ of the plaque bacterial population including Streptococcus sanguinis (S. sanguinis), Streptococcus mutans (S. mutans) [3]. S. sanguinis is a Gram-positive bacterium that is widely distributed in the oral environment, both in the teeth, mucosa, and saliva. These bacteria are facultative anaerobes that can live in the presence of oxygen and without oxygen, thus make them could be exist both in the supragingival and subgingival areas [4].

$S$. sanguinis is the predominant bacteria of the Streptococci species contained in dental plaque. Fimbria mediates the attachment of these bacteria to dental surface and further it binds to salivary component to support the plaque formation [5]. In addition, the toxin produced by the bacteria $S$. sanguinis will irritate the gingiva and then damage the periodontal [4].

Hibiscus flowers (Hibiscus rosa-sinensis L.) contain antibacterial compounds such as saponins, flavonoids, and tannins [6]. Flavonoids inhibit bacteria by forming complex compounds against extracellular proteins of bacterial cells that disrupt the integrity of the bacterial cell membrane. Saponins will damage bacterial cell membranes, resulting in protein and nucleic acid denaturation [7]. Tannins work by inhibiting the production of bacterial enzymes, and bind to cell walls and can destroy bacterial cell membranes [8].

Alternative compounds that act as antimicrobials that can inhibit plaque bacteria are important to find. Thus, the authors wanted to know the potential of hibiscus flower as an antimicrobial compound by investigating the effect of the concentration of hibiscus flower extract (Hibiscus rosa-sinensis L.) on the growth of Streptococcus sanguinis bacteria.

\section{Material and methods}

This study has been approved by the ethical research committee of Faculty of Dentistry, Universitas Gadjah Mada, Indonesia.

\footnotetext{
* Corresponding author: dlistyarifah@ugm.ac.id
} 


\subsection{Identification and collection of the samples}

The flower collected from Yogyakarta with the criteria as follow, has a red color, in full bloom, consisting of 56 petals and a flower diameter of around $10 \mathrm{~cm}$ and has been identified at the Plant Systematics Laboratory, Faculty of Biology, Universitas Gadjah Mada as Hibiscus rosa-sinensis $L$.

\subsection{Extraction}

The Hibiscus flowers were washed, cut into small pieces, then put in the dryer for 48 hours at $45^{\circ} \mathrm{C}$. The dried Hibiscus flowers are made into powder using a pollinator. Then the Hibiscus flower extract powder was macerated using 70\% ethanol, stirred until homogeneous, allowed to stand for 24 hours, then the extract was filtered through a Buchner filter funnel lined with filter paper to remove any impurity. The hibiscus flower pulp was mixed with ethanol, stirred and allowed to stand for 24 hours for the second filtration. The process of mixing the solution with ethanol was repeated once again and filtered. Then the filtrate was evaporated using an evaporator at a temperature of $70^{\circ} \mathrm{C}$. The filtrates then was diluted with distilled water until concentrations of $2 \%, 4 \%$, and $6 \%$ were obtained. These solutions were further subjected to antimicrobial assay.

\subsection{Culture preparation for antibacterial assay}

Stock culture of Streptococcus sanguinis used in this study were obtained from Integrated Research Laboratory, Faculty of Dentistry, Universitas Gadjah Mada, Indonesia.

Streptococcus sanguinis bacteria were transferred with sterile oses to the BHI broth bacterial culture medium, and incubated for 24 hours. The suspension was then centrifuged to obtain bacterial precipitate. The bacterial precipitate was suspended in $0.9 \% \mathrm{NaCl}$ until a bacterial suspension was obtained which corresponded to the standard McFarland turbidity level or equivalent to a concentration of $1.5 \times 10^{8} \mathrm{CFU} / \mathrm{ml}$ [8].

\subsection{Antibacterial assay}

Equipment and materials used were sterilized in an autoclave heated to a temperature of $121^{\circ} \mathrm{C}$ for 15 minutes [9]. After four petri dishes containing sterile BHI agar were prepared, 100 microliter of bacterial suspension were spreaded on the surface of the agar using glass bead to ensure even distribution then five well with a diameter of $5 \mathrm{~mm}$ were made on each plate using a punch in BHI agar [10].

Five tubes each containing $1 \mathrm{ml}$ of aquadest, $2 \%$, $4 \%$, and $6 \%$ of Hibiscus flower extract, $0.12 \%$ chlorhexidine were prepared. 50 microliter of each solution were added into the respective wells on each plates using a micropipette [8]. The plate were incubated for 24 hours at $37^{\circ} \mathrm{C}$ [11]. After 24 hours, the inhibition zone formed around the well was observed. The horizontal, vertical, and sloping lines were made at an angle of $45^{\circ}$ (Fig.1)[12].
The diameter of the inhibition zone was measured using a digital calliper with an accuracy of $0.01 \mathrm{~mm}$, then calculated by the equation for inhibition zone (Eq. 1)

Inhibition zone $=($ Measurement I + II + III $) / 3$

Information:

Point $\mathrm{O}:$ Center point of the well

Lines A-B, C-D, E-F : Radical zone formed

Lines a-b, c-d, e-f : Diameter of the well

Measurement I : (AB-ab)/2

Measurement II : $(\mathrm{CD}-\mathrm{cd}) / 2$

Measurement III : (EF-ef)/2

Equation 1. Formula to calculate the inhibition zone [12].

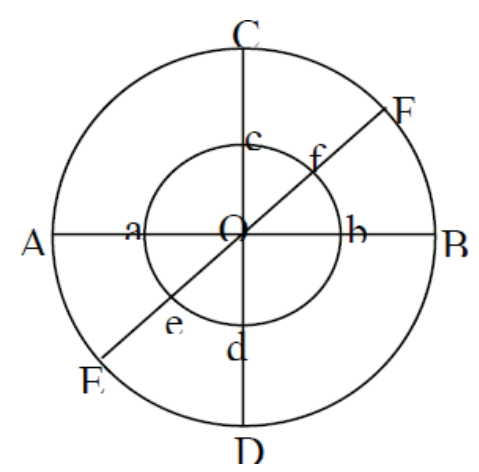

Fig. 1. The line to measure the inhibition zone [12]

\subsection{Statistical analysis}

Shapiro-Wilk and Levene's Test were used to analyze the normality and homogeneity of the data, respectively. The difference between the samples was assessed using a nonparametric method, the Kruskal-Wallis test followed by Mann-Whitney.

\section{Result}

The study of the effect of concentration of hibiscus flower extract (Hibiscus rosa-sinensis L.) on the growth of bacteria Streptococcus sanguinis have been carried out at the Integrated Research Laboratory, Faculty of Dentistry, Universitas Gadjah Mada.

The antibacterial activity of hibiscus flower extract on $S$. sanguinis was done by well diffusion method. The study subjects consisted of 5 groups, aquadest group as a negative control, hibiscus flower extract group with a concentration of $2 \%, 4 \%, 6 \%$, and $0.12 \%$ chlorhexidine group as a positive control. Each group consisted of 4 replicates.

The effect of the concentration of hibiscus flower extract on $S$. sanguinis was observed through the inhibition zone formed around the well. The zone of inhibition in this study was a clear zone formed around the wells which showed the antibacterial activity of the solution placed in the wells. Data of the zone of inhibition in each group are presented in Table 1. Table 1 showed that $6 \%$ of hibiscus flower extract showed the largest zone of inhibition $(6.35 \pm 0.09 \mathrm{~mm})$ compared to the other groups. The mean of inhibition zone of the $2 \%$ 
of hibiscus flower extract $(2.51 \pm 0.12 \mathrm{~mm})$ was lower compared to the positive control group $(3.09 \pm 0.33 \mathrm{~mm})$.

Table 1. The mean and standard deviation of treatment and control groups.

\begin{tabular}{lc}
\hline \multicolumn{1}{c}{ Treatment group } & $\begin{array}{c}\text { Mean } \pm \text { standard } \\
\text { deviation (mm) }\end{array}$ \\
\hline Negative control (aquadest) & $0.00 \pm 0.00$ \\
Hibiscus flower extract 2\% & $2.51 \pm 0.12$ \\
Hibiscus flower extract 4\% & $5.71 \pm 0.24$ \\
Hibiscus flower extract 6\% & $6.35 \pm 0.09$ \\
Positive control (chlorhexidine & $3.09 \pm 0.33$ \\
$0.12 \%$ ) & \\
\hline
\end{tabular}

The greater the mean of inhibition zone of bacterial growth is Hibiscus flowers extract $6 \%$ group (Fig. 2).

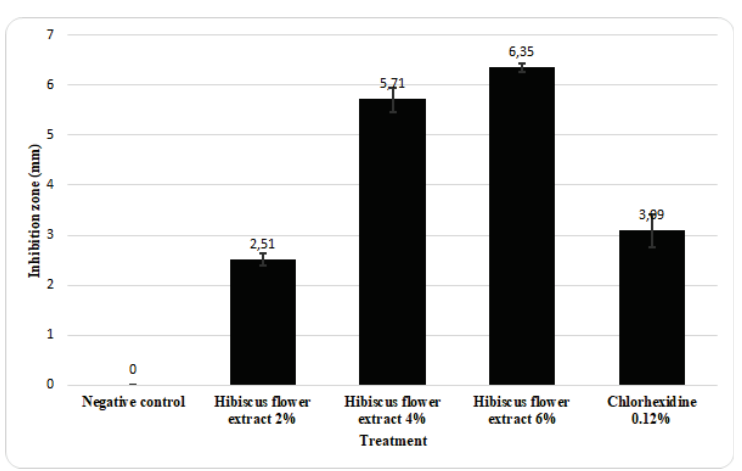

Fig 2. Effect of Hibiscus flower extract on Streptococcus sanguinis compared to control groups.

The normality of the data was tested with Shapiro-wilk and the homogeneity with Levene's test [9]. The results showed that the data of all groups were normally distributed $(\mathrm{p}>0.05)$ (Table 2).

Table 2. The results of the normality test using Shapiro-wilk

\begin{tabular}{cc}
\multicolumn{2}{c}{ test } \\
\hline Group & Significance \\
\hline Hibiscus flower extract 2\% & $0.935^{*}$ \\
Hibiscus flower extract 4\% & $0.629^{*}$ \\
Hibiscus flower extract 6\% & $0.058^{*}$ \\
Positive control & $0.263^{*}$ \\
chlorhexidine 0.12\% & \\
\hline
\end{tabular}
Description:

$$
: \mathrm{p}>0.05 .
$$

Table 3. Results of homogeneity using Levene's test

\begin{tabular}{cc}
\hline Statistic & Significance \\
\hline 14.633 & $0.000^{*}$ \\
\hline
\end{tabular}

Description:

$$
\text { * } \quad: p<0.05 \text {. }
$$

The Leven's homogeneity test is statistically significant $(\mathrm{p}=$ 0.000 ) which is indicate that the data is not homogeneous (Table 3). The data then was transformed, but the data still showed it is not homogenous. The results showed that the data was normally distributed but not homogeneous. These did not fulfil the requirements for the parametric test. As an alternative option, the data were tested non-parametrically with Kruskal-Wallis.

Table 4. Results of non-parametric test using KruskalWallis test

\begin{tabular}{lll}
\hline & \multicolumn{1}{c}{$\begin{array}{c}\text { Diameter of Zone of } \\
\text { Inhibition }\end{array}$} \\
\hline & Sig. & $0.001^{*}$ \\
\hline $\begin{array}{l}\text { Description: } \\
\text { Sig. }\end{array}$ & $\quad: \mathrm{p}<0.05$ \\
& $\quad$ Value significance
\end{tabular}

The result of Kruskal-Wallis test (Table 4) showed a significance value of $0.001(\mathrm{p}<0.05)$ meaning that the null hypothesis (Ho) is rejected and hypothesis 1 (H1) is accepted. This shows that the mean between groups is significantly different. Then the significant difference in the mean between each data group was analyzed using Mann-Whitney post-hoc test with a significance level $\mathrm{p}<0.05$ (Table 5).

The results of the Mann-Whitney test $(\mathrm{p}<0.05)$ have confirmed that the difference between treatments (all concentrations of hibiscus flower extract) and controls groups was statistically significant. This shows that there is an effect of concentration of hibiscus flower extract (Hibiscus rosa-sinensis L.) on the growth of bacteria Streptococcus sanguinis. In addition, the results also showed that the higher concentration $6 \%$ of hibiscus flower extract had a significantly larger zone of than the lower concentration. The mean inhibition zone of the $2 \%$ concentration of hibiscus flower extract.

Table 5. The results of Mann-Whitney test

\begin{tabular}{lc}
\hline \multicolumn{1}{c}{ Between groups } & Sig. \\
\hline $\begin{array}{l}\text { Hibiscus flower extract 2\% - Hibiscus flower } \\
\text { extract 4\% }\end{array}$ & $0,021^{*}$ \\
$\begin{array}{l}\text { Hibiscus flower extract 2\%- Hibiscus flower } \\
\text { extract 6\% }\end{array}$ & $0,020^{*}$ \\
$\begin{array}{l}\text { Hibiscus flower extract 2\%- Positive control } \\
\text { chlorhexidine } 0.12 \%\end{array}$ & $0,021^{*}$ \\
$\begin{array}{l}\text { Hibiscus flower extract 2\%- Aquadest } \\
\text { negative control }\end{array}$ & $0,014^{*}$ \\
$\begin{array}{l}\text { Hibiscus flower extract 4\%- Hibiscus flower } \\
\text { extract 6\% }\end{array}$ & $0,020^{*}$ \\
$\begin{array}{l}\text { Hibiscus flower extract 4\%- Chlorhexidine } \\
\text { positive control 0.12\% }\end{array}$ & $0,021^{*}$ \\
$\begin{array}{l}\text { Hibiscus flower extract 4\%- Aquadest } \\
\text { negative control }\end{array}$ & $0,014^{*}$ \\
$\begin{array}{l}\text { Hibiscus flower extract 6\% - Positive control } \\
\text { of } 0.12 \% \text { chlorhexidine }\end{array}$ & $0,020^{*}$ \\
$\begin{array}{l}\text { Hibiscus flower extract 6\% - Negative } \\
\text { control of aquadest }\end{array}$ & $0,013^{*}$ \\
$\begin{array}{l}\text { Positive control of } 0.12 \% \text { chlorhexidine - } \\
\text { Negative control of aquadest }\end{array}$ & $0,014^{*}$ \\
\hline $\begin{array}{l}\text { Description: } \quad \text { : }<0.05 \\
\text { Sig. } \quad \text { Value significance }\end{array}$ &
\end{tabular}

\section{Discussion}

This study aimed to determine the effect of the concentration of hibiscus flower extract (Hibiscus rosasinensis L.) on the growth of Streptococcus sanguinis bacteria. The effect of the concentration of hibiscus flower extract (Hibiscus rosa-sinensis L.) on the growth of Streptococcus sanguinis bacteria can be observed from the inhibition zone formed. The smallest inhibition zone was at a concentration of $2 \%(2.51 \pm 0.12 \mathrm{~mm})$ and the largest inhibition zone was at a concentration of $6 \%$ $(6.35 \pm 0.09 \mathrm{~mm})$. 
Previous study by Ruban and Gadjalaksmi (2012) [8] showed hibiscus flower extract with a concentration of $4 \%$ able to inhibit the growth of Staphylococcus aureus bacteria with a large zone of inhibition $(10.00 \pm 1.84$ $\mathrm{mm}$ ). Research by Seyyednejad et al. (2010) [13] showed that hibiscus flower extract was proven to inhibit the growth of Staphylococcus aureus bacteria at a concentration of $10 \%$ with an inhibition zone formed of $12 \mathrm{~mm}$, at a concentration of $20 \%$ by $16 \mathrm{~mm}$, and at a concentration of $40 \%$ by $20 \mathrm{~mm}$. Research by Missoum (2018) [14] showed that hibiscus flower extract with a concentration of $50 \%$ was able to inhibit bacterial growth Salmonella $s p$. and $P$. aeruginosa with large inhibition zone diameters of $20.40 \pm 1.54 \mathrm{~mm}$ and $16.30 \pm 0.94 \mathrm{~mm}$. This may be due to the content of hibiscus flowers, i.e various organic components such as flavonoids, tannins, terpenoids, and alkaloids which have been reported in vitro to have antimicrobial properties [8].

Based on a quantitative test with phytochemical analysis, hibiscus flower contains highest amount of flavonoids $(0.171 \mathrm{mg} / \mathrm{g}$ of hibiscus flower powder). Tannins amounted to $0.073 \mathrm{mg} / \mathrm{g}$ of hibiscus flower powder [15]. Flavonoids are natural substances with a phenolic structure, often found in fruits, flowers, leaves, and plant roots[18]. Flavonoids show antibacterial effect by inhibiting nucleic acid synthesis, inhibiting cytoplasmic membrane function, inhibiting energy for bacterial metabolism, and inhibiting biofilm formation [19]. Inhibition of cytoplasmic membrane function of flavonoids by binding to the extracellular membrane of bacteria and then dissolving the cell wall and bacterial cell proteins [8].

Hibiscus flowers also contain secondary metabolites in the form of polyphenolic compounds in addition to flavonoids, i.e tannins. Tannins are polyphenolic compounds that inhibit bacteria by denaturing bacterial cell proteins, the presence of tannins causes damage to the structure of bacterial cell membranes which are composed of proteins and lipids of bacterial cells [3]. In addition to its active component, hibiscus flowers also contain natural red pigments derived from anthocyanin components with an amount of $284 \pm 17 \mathrm{mg} / 100 \mathrm{~g}$ of hibiscus flower powder [15].

In this study, the group consisted of distilled water as a negative control, treatment group (hibiscus flower extract with concentrations of $2 \%, 4 \%$, and $6 \%$ ) and chlorhexidine as a positive control. Chlorhexidine is the gold standard of anti-plaque agent in reducing plaque and as a treatment for gingivitis by inhibiting and killing bacteria. Several studies have shown that chlorhexidine is able to damage the phospholipid components of bacterial cell membranes, causing irreversible leakage of cell membranes and killing bacteria [16]. The concentration of chlorhexidine used as a control was $0.12 \%$ since it was reported that the efficacy of chlorhexidine at both $0.12 \%$ and $0.2 \%$ was similar, therefore using a lower concentration would reduce chlorhexidine's side effects [17].

Based on the results and discussion above, hibiscus flower extract exhibit antibacterial activity against Streptococcus sanguinis bacteria. that may due to the antibacterial compounds contained in hibiscus flowers, flavonoids and tannins. However, further study to elaborate the potency of hibiscus flowers is still needed, such as toxicity tests in vitro and in vivo.

\section{Conclusion}

Present study shows that hibiscus flower extract able to inhibit the growth of Streptococcus sanguinis bacteria may be due to the antibacterial compounds contained in hibiscus flowers, i.e. flavonoids and tannins. In comparison of different concentrations of hibiscus flower extract, $6 \%$ of hibiscus flower extract shows the highest inhibition among others. This study suggests that hibiscus flower extract is a potential candidate as an adjuvant treatment in gingivitis and periodontitis. This may provide an experimental basis for further research to develop the utilization of hibiscus flower extract.

\section{References}

1. Vos, T. et al. 2017. Global, regional, and national incidence, prevalence, and years lived with disability for 328 diseases and injuries for 195 countries, 1990- 2016: A systematic analysis for the Global Burden of Disease Study 2016. The Lancet. 390(10100): 1211-59.

2. Murakami, S., Mealey, B.L., Mariotti, A., and Chapple, L.2017. Dental plaque- induced gingival conditions. Journal of Periodontology. 89(1): S17S27.

3. Zhu, B., Macleod, L.C., and Xu, P. 2018. Streptococcus sanguinis biofilm formation and interaction with oral pathogens. Future Microbiology. 13(8): 915-32.

4. Nasri and Imran, H. 2017. Efektifitas berkumur dengan larutan teh rosella dalam menghambat plak gigi serta mempercepat penyembuhan gingivitis pasca scaling. Aceh Nutrition Journal. 2(1): 18-24.

5. Okahashi, N., Nakata, M., and Terao, Y. 2011. Pili of oral Streptococcus sanguinis bind to salivary amylase and promote the biofilm formation. Microbial Pathogenesis. 50(3): 148-54.

6. Sari, Y.E.S. and Islamulyadin, M. 2017. Efektivitas Ekstrak Daun Kembang Sepatu (Hibiscus rosa-sinensis L.) terhadap Pertumbuhan Staphylococcus Aureus. The journal of Muhammadiyah Medical Laboratory Technologist. 1(2): $73-7$.

7. Safitri, L., Susilorini, T.E., and Surjowardjojo. 2017. Evaluasi anti mikroba (Streptococcus Agalactiae) menggunakan ekstrak buah mahkota buah (Phaleria Macrocarpa) dengan pelarut yang berbeda. Jurnal Ilmu dan Teknologi Hasil Ternak. 12(1): 8-15.

8. Ruban, P. and Gajalakshmi, K. 2012. In vitro antibacterial activity of Hibiscus rosa- sinensis L. flower extract against human pathogens. Asian Pacific Journal of Tropical Biomedicine. 2(5): 399-403.

9. Riwandy, A., Didit, A., and Lia, Y.B. 2014 Aktivitas ekstrak air kelopak bunga rosella 
(Hibiscus sabdariffa L.) terhadap pertumbuhan Streptococcus mutans in vitro. Dentino. 2(1): 604.

10. Singh, S., Gupta, A., and Verma, R. 2019. Antimicrobial and antioxidant potential of Hibiscus rosa-sinensis $L$. in western himalaya. Biology international journal. 11(1): 35-40.

11. Rozanna, R., Soedarsono, N., and Farida, R. 2017. Effect of propolis extract and propolis candies on the growth of Streptococcus sanguinis atcc 10556. Asian Journal of Pharmaceutical and Clinical Research. 10(5): 16-9.

12. Kartikasari I.A., Soelistiono, and Prihartiningsih. 2008. Pengaruh Ekstrak Batang Salvadora persica terhadap pertumbuhan bakteri Streptococcus ahaemolyticus hasil isolasi pasca pencabutan gigi molar ketiga mandibula (kajian in vitro). Fakultas Kedokteran Gigi Universitas Gadjah Mada. 1-6.

13. Seyyednejad, S.M., Koockhak, H., Darabpour, E., and Motamedi, H. 2010. A survey on Hibiscus rosa-sinensis, Alcea rosea L. and Malva neglecta Wallrs as antibacterial agents. Asian Pacific Journal of Tropical Medicine. 351-55.

14. Missoum, A. 2018. An updated review on Hibiscus rosa-sinensis phytochemistry and medicinal uses. Journal of Ayurvedic and Herbal Medicine. 4(3): 135-46.

15. Al-snafi, A.E. 2018. Chemical constituents, pharmacological effects and therapeutic importance of Hibiscus rosa-sinensis. Journal of pharmacy. 8(7): 101-19.

16. Mathur, S., Mathur T., Srivastava, R., Khatri, R. 2011. Chlorhexidine: The Gold Standard in Chemical Plaque Control. National Journal of Physiology, Pharmacy \& Pharmacology. 1(2): 4550 .

17. Najafi, M.H., Taheri, M., and Mehrara, R. 2012. Comparative study of $0,2 \%$ and $0,12 \%$ digluconate chlorhexidine mouth rinses on the level of dental staining and gingival indices. Dental research journal. 9(3): 305-8.

18. Panche, A.N., Diwan, A.D., and Chandra, S.R. 2016. Flavonoid. Journal of nutritional science. 5(1): 1-15.

19. Xie, Y., Yang, W., Tang, F., Chen, X., and Ren, L. 2015. Antibacterial activities of flavonoids: Structure-activity relationship and mechanism. Current medical chemistry journal. 22(1): 132-49. 